\title{
Peculiarities of Using Projects in Learning English as a Foreign Language
}

\author{
Sergei E. Drovosekov - Regina G. Sakhieva
}

DOI: 10.18355/XL.2018.11.01.09

\begin{abstract}
The purpose of this article is to create a theoretically grounded and experimentally verified methodology for project learning of English as a foreign language and to identify the peculiarities of its application in practice. The authors have developed step-by-step methodical recommendations on the organization of the project activity of schoolchildren at the senior level of education in the secondary school on the example of some topic. Features of the authors' approach to the study of the peculiarities of project learning is the introspective analysis of pedagogical and methodological works which are compared with the approaches of foreign and national scientific schools to the project activity; a precise scale of project evaluation; an allocation of a separate speech stage for the preparation of the project. The study revealed the effectiveness of project learning of English as a foreign language. The materials of the article are of value for teachers of the senior classes of the secondary school and higher educational institutions.
\end{abstract}

Key words: project learning, project method, project, communicative method, crosscultural communication

\section{Introduction}

\subsection{The relevance of the problem}

Since the 21 st century is characterized by the globalization in different spheres of human activity and processes of integration in the field of education, it should be noted that the English language as a means of intercultural communication stimulates the movement of society to search for the new forms and models of teaching, which are maximally oriented toward independence, creativity, autonomy, and ability to selfeducation (Galushkin, 2015).

The need for continuous improvement of the system and practice of education is justified by social changes taking place in society. At present, the teacher is not the only source of information, and information sources are not just articles of encyclopedias. Since the emergence and development of the Internet, the availability and abundance of information make it extremely important to be able to use electronic sources, to find the necessary information, to process and systematize, thus obtaining quality knowledge and skills that can be used in practice (Kostikova, 2014).

The necessary tasks for high schoolchildren are: to develop the skills of research, creative activity using information technology; active learning, research activities and participation in group projects; exchange of experience. The project work involves "mastering the methods of activity applicable to a wide range of impact objects (for example, analysis, an organization of team interaction). The project work allows schoolchildren to form an important internal resource that does not form specifically in other components of the educational process at school" (Apakina, 2011; Sutinen, 2013).

\subsection{Aims and objectives of the research}

The purpose of this article is to create a theoretically grounded and experimentally verified methodology for project learning of English as a foreign language and to

XLinguae, Volume 11 Issue 1, January 2018, ISSN 1337-8384, eISSN 2453-711X 
identify the features of its application at the senior stage of education (10-11 grades) of the secondary school.

To achieve the purpose of the research, it was necessary to solve the following main tasks:

to generalize main methodological and theoretical approaches to the study of the application of the project method, to determine the specifics of the application of the project method when teaching schoolchildren a foreign language, to determine the sequence of cognitive actions of schoolchildren while preparing and conducting project activities, to develop a system of tasks for preparing schoolchildren for project activities, to identify conditions for using the project method in order to form sustainable motivation and development of cognitive interests of schoolchildren, to develop a criterion and external evaluation of the effectiveness of project activities for the formation of the communicative competence of schoolchildren at the senior stage of secondary schools.

\section{Literature Review}

\subsection{Analysis of Russian scientific and pedagogical literature}

Project learning is not fundamentally new in pedagogy. S.T. Shatsky (1980), K.N. Wentzel (1923), B.V. Ignatiev (1930). E. G. Kagarov (1926) studied ideas of project learning in the early twentieth century in Russia. According to the authors, the project most successfully prepares schoolchildren for independent adult life, develops the skills of collective work, which requires the teacher to be qualified and fully developed. S.T. Shatsky (1980) studied the creation of the most favorable conditions for the natural development of the child, versatile work as a pedagogical means of organizing normal childhood, school self-government. Then the method of projects in the domestic pedagogy was forgotten.

At the present stage of the development of methodology in Russia, the project method has become popular again in scientific studies of E.S. Polat et al. (2002), I.Yu. Solovyova (2000), O.S. Vinogradova (2003), A.P. Kuznetsova (2002), I.A. Zimnyaya and T.E. Sakharova (1991). The authors note that project learning allows solving the tasks of forming and developing cognitive skills of schoolchildren, the ability to independently built their knowledge, develop research skills and system thinking, as at different moments of cognitive, experimental or applied creative activity, school children use a combination of all intellectual skills.

According to G.K. Selevko (2006) and S.V. Somova (2011), the project in the context of education is an effective activity, performed in specially organized by the teacher conditions, which gives the learner the opportunity to act independently, to receive the result. G.K. Selevko (2006) defines the creative educational project as "an independently developed and manufactured product (material or intellectual) from the idea to its implementation, possessing subjective or objective novelty, performed under the supervision of the teacher."

Analyzing scientific works of Russian authors T.S. Ruzhentseva, Yu.A. Yermoshin \& I.I. Molchanova (2017), T.P. Martynenko (2016), we can note the tendency that teachers start to use project teaching not only at schools but also in higher educational institutions.

\subsection{Analysis of foreign works}

Abroad the method of projects was first implemented experimentally, verifying its effectiveness in practice. American professor E. Collings (1926) gave a detailed description of the use of project learning at schools and compared the results of experimental and test schools. The study states that the curriculum "can be fully selected from the goals set by children in real life.» 
The method of projects as it is used today inherited only a number of features of the original plan: taking into account the interests of schoolchildren when distributing tasks within the group in the collective implementation of the project, specific characteristics of students' activities and teacher's functions at different stages of joint activity (Celuch, Bourdeau, Smothers, 2014).

M. Gibbes, L. Carson (2014) examine the effectiveness of the project method in studying the language from the point of view of results that are theoretically consistent with the object of activity and different for each student. For some subjects, projects were seen as an effective way to achieve the goal of the activity or their true motive. For others, the results do not agree with the object of their activity, and it leads to negative experience.

E. Mikulec, P.Ch. Miller (2011) analyze how much project learning meets state and other educational standards. They point out that the project method helps language learners meet international standards established by the American Council for the Teaching of Foreign Languages. Thus, the project activity corresponds to universally recognized world standards in the field of education, which shows the urgency of using this method in Russian educational institutions.

According to E.A. Penkovskykh (2010), the use of the project method in Russia and in the West pursued different goals. American teachers used it as one of the ways to awaken and maintain the students' interest in the learning process; they tried to ensure that the completed project would bring the child a concrete personal benefit and his results could be used in everyday life. Soviet teachers used the method of projects in order to develop a children's desire to work for society and contribute to the common deed. The projects were mostly public. In America, the method of projects was used along with the class system, in the USSR this method tried to displace all others. Currently, project learning is used in Russian schools and other educational organizations by the American type, being an element of learning activity.

\section{Materials and Methods}

\subsection{Theoretical, empirical and statistical methods}

To confirm the hypothesis of the study, the author used both theoretical and empirical research methods:

- theoretical methods: review of pedagogical and methodological literature on the research problem; analysis of methodological developments, educational standards and other educational materials; theoretical analysis of the proposed project technologies and techniques, the method of substantive generalization; on the basis of these methods the author presents theoretical substantiation of the system of working with schoolchildren of the upper grades of the secondary school for mastering the program of English as a foreign language;

- empirical methods: monitoring of students' activity, confirming and forming the pedagogical experiment, questioning, testing, analysis of the results of experimental work.

- statistical methods: qualitative and quantitative analysis of research results, ranking

\subsection{The base of the research}

The study was carried out on the basis of the school No. 5 in Kotelnich (the municipal budgetary general educational institution, an average secondary school with an indepth study of individual subjects No. 5 in the city of Kotelnich in the Kirov region). Twenty-two schoolchildren (of 10 grade) took part in the experiment.

\subsection{Stages of the research}

The research had three stages:

XLinguae, Volume 11 Issue 1, January 2018, ISSN 1337-8384, eISSN 2453-711X 
The first stage included the selection, study and theoretical analysis of the psychological, pedagogical and methodological literature on the research topic; the author formulated the hypothesis, goals, and objectives of the study, its structure. There was established an experimental site on the basis of the School No. 5 in Kotelnich, the level of preparedness of students, their motivation, and involvement in the educational process were analyzed.

At the second stage, the author studied the educational program and the methodological complex on the subject, worked out the program plan for the project on the topic "Western democracies. Are they democratic?". The author corrected the general conception of the study, conducted an educational experiment in the 10th grade of the school, established an experimental site on its basis. The experiment involved 22 people.

The third stage summed up the results of the experiment: a quantitative and qualitative analysis of the experimental results, their systematization, and interpretation; final conclusions on the research topic. The approbation of the research topic was carried out in the author's publications and speeches at scientific conferences.

\subsection{Evaluation Criteria}

Despite the fact that the project activity in the Russian school exists for a relatively long time, teachers often evaluate the projects of students guided by their subjective impressions. It is more correct for this purpose, to use a certain set of criteria for the evaluation of the project product, with which it is necessary to familiarize students beforehand (Makarova, 2015).

In assessing the effectiveness of the project, the following criteria are applied:

1. The purpose. If it is not formulated - 0 points. It is formulated, but not justified - 1 point. It is clearly stated but justified in general terms - 2 points. The purpose is defined, formulated, clearly substantiated - 3 points.

2. Planning ways to achieve the purpose of the project. There is no plan - 0 points. The plan does not meet the goal - 1 point. Short plan, consists only of the main stages of the project - 2 points. The detailed plan consists of the main stages and intermediate steps to achieve the purpose of the project -3 points.

3. The depth of disclosure of the project topic. The topic is not disclosed - 0 points. The topic is not fully disclosed - 1 point. The author showed the disclosure of the topic within the school program - 2 points. The author demonstrated a profound knowledge beyond the school curriculum -3 points.

4. The diversity of sources of information, the expediency of their use. Incorrect information is used - 0 points. Most of the information does not correspond to the topic -1 point. A small amount of suitable information was used from a limited number of sources of the same type - 2 points. The complete information from various sources is presented -3 points.

5. Analysis of the working process, conclusions, and prospects. No attempt was made to analyze the course and the result of the work - 0 points. The analysis was replaced by a description of the working process - 1 point. A detailed review of the work to achieve the stated goals is presented - 2 points. An exhaustive analysis of the situations of the project work is presented, prospects are outlined - 3 points.

6. Personal interest. Work has a template, formal design - 0 points. There was little interest; the creative potential was not used - 1 point. Serious interest, elements of creativity - 2 points. Creativity, original attitude -3 points.

7. Compliance with the writing requirements. The written part is missing - 0 points. There is no strict order, no structure - 1 point. Attempts have been made to formalize the work in accordance with the established rules - 2 points. Clear and competent writing part - 3 points.

8. Quality of presentation. There was no presentation - 0 points. Appearance and 
speech of the author do not correspond to the rules of presentation - 1 point. Appearance and speech of the author correspond to the rules of presentation, but the author does not know the culture of communication - 2 points. The appearance and speech of the author correspond to the rules of presentation, the author owns a culture of communication, meet the rules, he manages to evoke great interest - 3 points.

9. Quality of the project product. There is no project - 0 points. It does not meet the quality requirements (aesthetics, usability, compliance with the stated goals) - 1 point. It does not fully meet the quality requirements - 2 points. It fully meets the quality requirements - 3 points.

These criteria for project evaluation make it possible not only to comprehensively and correctly assess the project but also allow the teacher to conclude what further work should be done for students who have shown not very good results by any of the criteria.

\subsection{Progress and description of the experiment}

The research was carried out on the basis of school No. 5 in Kotelnich, Kotelnich district, Kirov region. Twenty-two students of school №5 took part in the experiment. The analysis of textbooks and teaching aids in English showed that students are taught according to the educational and methodical set of "English" by V.P. Kuzovlev, N.M. Lapa \& E.Sh. Peregudova (2009), designed for students of the secondary school who study English as a foreign language. The teaching package assumes the project activities of students on each subject block. In this research, the author worked out a project on the topic "Western Democracies. Are They Democratic?".

The working title of the project "An Ideal State, as I Understand It." The project activities of the students had several stages:

- preliminary stage - familiarizing students with the topic, motivating, identifying the problem, setting goals and objectives, forming groups;

- speaking stage - study of lexical and grammatical material necessary for effective work on the project;

- analytical stage - coordination of the overall project development line, formation of groups, drawing up of a detailed working plan for the project, discussion of ways of collecting information and carrying out the search work, discussion of the first results in the group;

- practical stage - design work on the project;

- presentation stage - presentation of the results of the project activity, evaluation, analysis.

\section{Results}

\subsection{Preliminary stage}

Work on the project began at the first lesson of the section from the formulation of the problematic issue "Western Democracies. Are They Democratic?" Here the schoolchildren made suggestions about what they learn from this section and what they will learn to speak, listen and write in English.

At this stage, the main task of the teacher is to evoke interest to the topic and to adjust the students to the perception of the material, which will determine the success of subsequent stages of work on the project. 
Table 1. Choosing the topic of the project

\begin{tabular}{|c|c|c|c|}
\hline $\begin{array}{l}\text { Title of } \\
\text { the } \\
\text { project }\end{array}$ & Tasks & $\begin{array}{l}\text { Leading } \\
\text { activity }\end{array}$ & Notes \\
\hline $\begin{array}{l}\text { An Ideal } \\
\text { State, } \\
\text { as I } \\
\text { Underst } \\
\text { and It }\end{array}$ & $\begin{array}{l}\text { To inform students about the } \\
\text { overall picture Unit } 2 \text { Western } \\
\text { Democracies. Are They } \\
\text { Democratic? } \\
\text { On topics: } \\
\text { Part 1. Parliamentary Democracy. } \\
\text { How Does It Work? } \\
\text { Part 2. Section 2. How Much } \\
\text { Power Does the Us President } \\
\text { Have? } \\
\text { Part 3. What Political System } \\
\text { Does Russia Belong To? } \\
\text { Reading section. Who Is More } \\
\text { Equal? } \\
\text { Part 4. Must a Politician Be Kind? } \\
\text { Part 5. Who'd Have Thought It? } \\
\text { Part 6. Are You a Good } \\
\text { Lawmaker? }\end{array}$ & $\begin{array}{l}\text { Conversation } \\
\text { with } \\
\text { schoolchildren }\end{array}$ & $\begin{array}{l}\text { Students are } \\
\text { offered to } \\
\text { answer the } \\
\text { question: } \\
\text { What state is } \\
\text { really } \\
\text { democratic? }\end{array}$ \\
\hline
\end{tabular}

\subsection{Speaking stage}

This stage is singled out separately since insufficiently developed communication skills prevent the most effective implementation of project work at schools. The subsequent stages of work on the section were carried out in the traditional (familiar to students) form: exercises from the textbook, implementation of lexical and grammatical exercises. Gradually the vocabulary and grammatical skills were combined, and we could start the work on the project.

Table 2. Speech skills training

\begin{tabular}{|l|l|l|l|}
\hline $\begin{array}{l}\text { Title of the } \\
\text { project }\end{array}$ & Tasks & $\begin{array}{l}\text { Leading } \\
\text { activity }\end{array}$ & Notes \\
\hline $\begin{array}{l}\text { An Ideal } \\
\text { State, } \\
\text { as I } \\
\text { Understand It }\end{array}$ & $\begin{array}{l}\text { 1. Learning new } \\
\text { vocabulary. } \\
\text { 2. Learning grammar } \\
\text { 3. Improving listening } \\
\text { and speaking skills }\end{array}$ & $\begin{array}{l}\text { All types of } \\
\text { activities }\end{array}$ & $\begin{array}{l}\text { Students get acquainted } \\
\text { with the political } \\
\text { structure of their } \\
\text { country and the } \\
\text { countries of the studied } \\
\text { language, receive } \\
\text { information on the } \\
\text { realities of political life }\end{array}$ \\
\hline
\end{tabular}

\subsection{Analytical stage}

At this stage of project development, groups were formed to solve various problems. When they were formed, the teacher had to take into account not only the external differentiation, the personal sympathies of students in the classroom, but also the possibility of creating the most favorable atmosphere for the formation of personal experience sources for students with different intellectual and creative potential, the best ways to address their personal sphere when working on a project in a group or pair. 
Table 3. Distribution of roles

\begin{tabular}{|c|c|c|c|}
\hline $\begin{array}{l}\text { Title of } \\
\text { the project }\end{array}$ & Tasks & $\begin{array}{l}\text { Leading } \\
\text { activity }\end{array}$ & Notes \\
\hline $\begin{array}{l}\text { An Ideal } \\
\text { State, } \\
\text { as I } \\
\text { Understan } \\
\text { d It }\end{array}$ & $\begin{array}{l}\text { 1. Formation of working } \\
\text { groups } \\
\text { 2. Discussing topics in } \\
\text { groups, selecting a section, } \\
\text { selecting partners, creating } \\
\text { working groups. } \\
\text { 3. Allocation of the } \\
\text { responsible people in the } \\
\text { group (leaders), distribution } \\
\text { of the functions of the group } \\
\text { members }\end{array}$ & Group work & $\begin{array}{l}\text { Students are invited } \\
\text { to present their } \\
\text { vision of an ideal } \\
\text { state }\end{array}$ \\
\hline
\end{tabular}

4 working groups were formed: 5 people, 5 people, 6 people, 6 people; preparation of 4 projects at the same time.

Working with the teacher, schoolchildren had an opportunity to analyze their activities together with the teacher, choose and defend the point of view, draw certain conclusions in the political sphere, value attitude. At this stage, the teacher works as a consultant, the attention of the students was emphasized on the content.

\subsection{Practical stage}

At this stage, there was a collection of all material, discussion of the final presentation. Preparation for the final lesson was done by the students themselves due to the limited time available in the lesson. The teacher didn't interfere actively, only monitored the work of each student and the group as a whole.

Table 4. Work on the project

\begin{tabular}{|l|l|l|l|}
\hline $\begin{array}{l}\text { Title of the } \\
\text { project }\end{array}$ & Tasks & Leading activity & Notes \\
\hline $\begin{array}{l}\text { An Ideal } \\
\text { State, Independent } \\
\text { as } \\
\text { Understand It } \\
\text { work } \\
\text { projects }\end{array}$ & & $\begin{array}{l}\text { Individual work, } \\
\text { group work }\end{array}$ & $\begin{array}{l}\text { In each lesson, group } \\
\text { leaders present brief } \\
\text { overview of the } \\
\text { progress of the } \\
\text { project, together with } \\
\text { participants from } \\
\text { other groups, give } \\
\text { recommendations. }\end{array}$ \\
\hline
\end{tabular}

\subsection{Presentation stage}

One of the important steps in the implementation of the project is its presentation. It concludes, sums up the work on the project and is important for both students and teachers, who must plan the course and form of the presentation from the very beginning of the project.

At the stage of project development, when the discussion was underway, speech skills such as speaking and listening were added to the work. When the students selected material and made notes, reading and writing were added. During the presentation, students chose collage forms and multimedia presentations to present the results of the project activities. Thus, as basic skills, schoolchildren demonstrated oral speech and writing. 
Table 5. Presentation of the project

\begin{tabular}{|l|l|l|l|}
\hline $\begin{array}{l}\text { Title of the } \\
\text { project }\end{array}$ & $\begin{array}{l}\text { Leading } \\
\text { activity }\end{array}$ & Notes \\
\hline $\begin{array}{l}\text { An Ideal } \\
\text { State, } \\
\text { as } \\
\text { Understand It }\end{array}$ & $\begin{array}{l}\text { 1. Presentation of the } \\
\text { results of the project } \\
\text { activity, } \\
\text { 2. Evaluation, analysis }\end{array}$ & $\begin{array}{l}\text { Individual } \\
\text { work, work } \\
\text { in pairs }\end{array}$ & $\begin{array}{l}\text { Students choose one } \\
\text { or two people who } \\
\text { represent the project } \\
\text { to the class }\end{array}$ \\
\hline
\end{tabular}

To present the results of the project activity, the students selected collage forms and multimedia presentations. Group 1 of 5 people presented a collage, focusing on the personality of the head of state. Group number 2 of 5 people prepared a multimedia presentation on the laptop, focusing attention on such details as the original coat of arms, anthem and other attributes of power. Group 3 presented a state-utopia with a set of rights and freedoms of citizens, some of which were comic, but the other part was drafted fairly legally. Group 4 showed the least interest in the project, but the formal presentation in the form of a poster contained drawings by hand, which demonstrated the creative skills of the group members.

Table 6. Evaluation of the project

\begin{tabular}{|l|c|c|c|c|}
\hline Evaluation criteria & Group №1 & Group №2 & Group №3 & Group №4 \\
\hline 1. The purpose & 3 & 3 & 2 & 3 \\
\hline $\begin{array}{l}\text { 2. Planning ways to } \\
\text { achieve the purpose of } \\
\text { the project }\end{array}$ & 3 & 2 & 2 & 2 \\
\hline $\begin{array}{l}\text { 3. The depth of } \\
\text { disclosure of the } \\
\text { project topic }\end{array}$ & 3 & 3 & 3 & 2 \\
\hline $\begin{array}{l}\text { 4. Diversity of } \\
\text { sources } \\
\text { information, } \\
\text { expediency of their us }\end{array}$ & 3 & 3 & 3 & 3 \\
\hline $\begin{array}{l}\text { 5. Analysis of the } \\
\text { working process, } \\
\text { conclusions, and } \\
\text { prospects }\end{array}$ & 2 & 1 & 2 & 2 \\
\hline 6. Personal interest & 3 & 3 & 3 & 2 \\
\hline $\begin{array}{l}7 . \quad \text { Compliance with } \\
\text { the writing } \\
\text { requirements }\end{array}$ & 2 & 3 & 3 & 3 \\
\hline $\begin{array}{l}8 . \quad \text { Quality of the } \\
\text { presentation }\end{array}$ & 3 & 3 & 3 & 3 \\
\hline $\begin{array}{l}\text { 9. Quality of the } \\
\text { project product }\end{array}$ & 3 & 24 & 24 & 21 \\
\hline Total & 25 & & & 3 \\
\hline
\end{tabular}

Excellent $-27-24$

Good - 23-20

Satisfactory $-19-14$

$\mathrm{Bad}-13-0$

Thus, the organized project activity of students provided active learning practice for each student, in the course of the project activity, the students developed skills in 
speaking (monologic and dialogical speech) and communicative competence outside the language environment.

\section{Discussions}

The practical research conducted at the secondary school No. 5 in Kotelnich, Kirov region, made it possible to come to the following conclusions: the organized project activity of students provides active language teaching practice for each student; the use of the project method in organizing the activities of students in the English language lesson allowed each 10th grade student to demonstrate his/her ability to express his or her opinion in a foreign language; in the course of project activities, students developed skills in speaking (monologic and dialogical speech) and communicative competence; the fulfillment of project assignments made it possible to make English lessons more diverse, shifting the emphasis from various types of exercises to active thinking and creative activity of students; in real practice, it is possible to organize work on the implementation of a mixed-type project more often; in the project learning the role of the teacher is much more complicated than in traditional teaching, the projects of political topics are of interest to the students of the senior stage; project assignments will allow students to use the possibilities of using their knowledge of a foreign language.

\section{Conclusion}

Summarizing the results of the theoretical and practical research, it is clear that the personality-oriented approach to teaching a foreign language and the design methodology is understood as some progressive trend in general pedagogy and psychology, in particular, in the context of the problems of the educational role of the learning process.

The method of projects as modern pedagogical technology is a way of organizing the process of teaching a foreign language based on the interaction of the teacher and students in the course of step-by-step activities to achieve the goals and is characterized by high student autonomy, reliance on personal needs, the characteristics and experience of students, the availability of specific practical results. When using project activities in teaching English, it is necessary to take into account the specifics of the subject that directly influences the organization of the project activity, namely: it assumes, for the most part, a group project work with emphasis on the communicative side of the process, additional work on the selection of language material and the importance of presenting the results.

In order to overcome the difficulties in organizing the project work in the English language classes and to increase the efficiency of the use of technology, a set of conditions must be taken into account, including: taking into account the relationships within the team of project participants, the competent formation of groups, timely monitoring and advice on the progress of the project, participants of the project, development of project activity skills, etc.

The materials of this article can be useful for teachers of secondary schools and teachers of secondary professional and higher education institutions using project learning of English as a foreign language.

\section{Acknowledgments}

The study was carried out with the financial support of the State Assignment of The Ministry of Education and Science of the Russian Federation "Teacher Training Technologies in a Classical University Environment," the project № 27.9412.2017/8.9. 


\section{Bibliographic references}

APAKINA, L.V. 2011. Modeling of the communicative and creative independence of foreigners in the electronic environment (level A1-A2). PhD Thesis. Moscow: Peoples' Friendship University of Russia.

GALUSHKIN, A.A. 2015. Education in the Field of National Information Security in the Russian Federation and Abroad. In: Journal of Computer Science, vol. 11, n. 10, 988-994. ISSN Print: 1549-3636. ISSN Online: 1552-6607.

COLLINGS, E. 1926. Experience of the American school on the method of projects. Moscow: New Moscow.

GIBBES, M. - CARSON, L. 2014. Project-based language learning: an activity theory analysis. In: Innovation in Language Learning and Teaching, vol. 8, n. 2, pp. 171-189. ISSN 17501237, 17501229

IGNATIEV, B.V. 1930. On the way to the method of projects. Moscow: Worker of the Enlightenment.

KAGAROV, E.G. 1926. The method of projects in the labor school. Leningrad: Brockhaus-Efron.

KILPATRICK, W.H. 1925. Project method. Application of the target setting in the pedagogical process. Leningrad: Brockhaus-Efron.

KOSTIKOVA, L.P. 2014. Formation of intercultural competence of university students in a virtual educational environment. In: European Social Science Journal, vol. 8, n. 2(47), pp. 72-79. ISSN 2079-5513.

KUZNETSOVA, A.P. 2002. Realization of the national-regional component of the content of teaching foreign languages in an integrated course on a project basis (senior school, English). PhD Thesis. Moscow: Moscow State Pedagogical University.

KUZOVLEV, V.P. - LAPA, N.M. - PEREGUDOVA, E.Sh. 2009. English. 10-11 grades. Moscow: Prosveshchenie. ISBN 978-5-09-020525-2.

MAKAROVA, L.A. 2015. Training for the implementation and evaluation of projects in English. In: Young Scientist, vol. 14, pp. 492-494. ISSN 2072-0297.

MARTYNENKO, T.P. 2016. The use f innovative technologies in the learning of the English language in the higher education. In: Models of citizen participation in the social and economic life of the Russian society, vol. 2, pp. 73-76. ISBN 978-5-98566121-7.

MIKULEC, E. - MILLER, P.Ch. 2011. Using Project-Based Instruction to Meet Foreign Language Standards. In: The Clearing House: A Journal of Educational Strategies, Issues and Ideas, vol. 84, n. 3, pp. 81-86. ISSN: 0009-8655.

PENKOVSKYKH, E.A. 2010. The method of projects in domestic and foreign pedagogical theory and practice. In: Issues of education, vol. 4, pp. 307-319. ISSN: 1814-9545.

POLAT, E.S. - BUKHARKINA, M.Yu. - MOISEEVA, M.V., PETROV, A.E. 2002. New pedagogical and information technologies in the educational system. Moscow: Academy Publ. ISBN 5-7695-0811-6.

RUZHENTSEVA, T.S. - YERMOSHIN, Yu.A. - MOLCHANOVA, I.I. 2017. The use of project methodology in teaching English to students of information technology specialties Humanitarian education in an economic institution. In: V International Scientific and Practical Distance Learning Internet Conference, pp. 324-327.

SELEVKO, G.K. 2006. Encyclopedia of educational technology. Moscow: Research Institute of School Technology. ISBN 5-87953-227-5.

SHATSKY, S.T. 1980. Selected pedagogical compositions: in 2 parts. Moscow: Pedagogika.

SOLOVYOVA, I.Yu. 2000. Methodical foundations for the creation of the course "Country Studies in Britain" using the project method. PhD Thesis. Moscow: Russian Academy of Education Institute of General and Secondary Education. 
SOMOVA, S.V. 2011. Modern educational technologies and methods aimed at the formation of professional competence of teachers of a foreign language. In: Quality management in education: theory and practice XVIII Ryazan pedagogical readings, dedicated to the memory of Professor A.N. Kozlova, pp. 60-61. ISBN 978-5-88006701-5.

SUTINEN, A. 2013. Two Project Methods: Preliminary observations on the similarities and differences between William Heard Kilpatrick's project method and John Dewey's problem-solving method. In: Educational Philosophy and Theory, vol. 45, n. 10, pp. 1040-1053. ISSN: 1469-5812.

VINOGRADOVA, O.S. 2003. Formation of a foreign communicative competence using problematic methods of teaching AI at an advanced stage of a specialized higher education institution. PhD Thesis. Moscow: Russian Academy of Education Institute of General and Secondary Education Publ.

WENTZEL, K.N. 1923. New ways of upbringing and education of children. Moscow: Land and Factory Publ.

ZIMNYAYA, I.A. - SAKHAROVA, T.E. 1991. Project methodology for teaching English language. In: Foreign languages at school, vol. 3, pp. 9-15. ISSN 0130-6073

CELUCH, K. - BOURDEAU, B. - SMOTHERS, J. 2014. Thinking Innovatively about Teaching Innovation and Ideation: Getting Students to Think Differently. In: The Journal of Research in Innovative Teaching, vol. 7, n. 1, pp. 27-37. ISSN 19471017.

Words: 4930

Characters: 31847 (17,69 standard pages)

Senior Lecturer Sergei E. Drovosekov

Department of Pedagogics and Psychology

Vyatka State University

36 Moskovskaya Str.

610000 Kirov

Russia

se_drovosekov@vyatsu.ru

Assoc. Prof. Regina G. Sakhieva, PhD,

Institute of Psychology and Education

Kazan (Volga region) Federal University

18 Kremlyovskaya Str.

420008 Kazan

Russia

saxievarg@mail.ru 